rban housing in Aotearoa New Zealand is predominantly unit-titled, individualised dwellings whether the housing is owneroccupied or a rental investment. As housing increases in density, the provision and management of common space becomes necessary. In Aotearoa New Zealand, when this occurs, the extent of privately owned housing space is typically privileged, and shared common space minimised. In contrast, cooperative housing integrates housing, economic factors, and social contexts to create long-term socially and economically sustainable housing. Since the $19^{\text {th }}$ century, cooperative housing has provided evidence of internationally awarded and recognised, self-help, communitygenerated housing that includes shared components. Cooperative housing offers a third way of achieving affordable housing security, one that lies between home ownership and renting. Legislatively mandated and protected cooperative housing is needed in Aotearoa New Zealand to augment our existing housing production systems and types, and to help address the need for enduring, affordable, and socially sustainable housing. 


\section{Re-socialising Aotearoa New Zealand Housing}

\section{MARK SOUTHCOMBE}

New Zealand governments once aspired to provide access to state housing to all citizens. ${ }^{1}$ This vision is a distant utopian memory and today's government policy must react to the extreme effects of an increasingly serious and urgent housing supply and affordability crisis. In this context, it can be difficult to imagine that another successful approach to affordable housing provision exists, and that it could offer a practical means of generating ever-expanding quantities of affordable housing.

Compared to urban housing in Europe and the United Kingdom, New Zealand urban housing is distinctive for being predominantly comprised of unit-titled, individualised dwellings - whether the housing is owner-occupied, or a rental investment occupied by tenants. As housing increases in density and is part of a larger grouping, as seen with medium-density housing or apartment buildings, common space provision and management become necessary. In Aotearoa New Zealand, privately owned housing space is typically privileged, and shared common space minimised. Collective housing ownership structures are less favoured, and we do not have formalised cooperative housing ownership,

1 Bill McKay and Andrea Stevens, Beyond the State: New Zealand State Houses from Modest to Modern (Auckland: Penguin, 2014), 11. 
governance, and management structures. ${ }^{2}$

Cooperative housing, as a model, integrates housing, economic factors, and the broader social context to create long-term socially and economically sustainable housing. Since the $19^{\text {th }}$ century, cooperative housing projects have provided evidence of long-term, self-help, community-generated housing with shared components. Cooperatives as a type of housing have been internationally recognised and awarded for contributions to long-term affordable and socially focussed housing provision. ${ }^{3}$ Cooperative housing offers a third way for achieving affordable housing security, one that lies between home ownership and rental models. Legislatively mandated cooperative housing design that facilitates and protects occupants' rights is precisely what is needed in Aotearoa New Zealand. It would augment our existing housing production systems and types and would help address the need for enduring, better quality, affordable, and socially sustainable housing. This article fleshes out a vision for a world-leading Aotearoa New Zealand cooperative housing sector and discusses practical steps that can be taken to realise this vision.

\section{Housing affordability and investment}

Housing scarcity and unaffordability in Aotearoa New Zealand is well known. ${ }^{4}$ A lack of access to reasonable quality long-term housing is endemic and visible in increasing homelessness on city streets and growing housing

2 Historically, there have been some forms of shared property ownership including Māori land. Until the introduction of the Unit Titles Act 1972, the New Zealand legal system also accommodated company share property with land held in common by a company and owners with a right to occupy an apartment. Some company share apartments still exist. Each of these operates according to their particular company rules, some of which may be broadly similar to cooperative housing.

3 Visit: https://www.world-habitat.org/world-habitat-awards/winners-and-finalists/ more-than-housing/\#outline

4 J. E. Tookey, 'The Mess We're In: Auckland's Housing Bubble from a

Construction Sector Perspective,' Auckland, The Policy Observatory, April 2017. 
inequality. ${ }^{5}$ This inequality is evident in the contrast between oversized executive-standard monster houses, which have multiple rooms and bathrooms for two occupants, and tiny houses with minimal floor area and services designed to circumvent building standards, to be movable without a permanent site, and which accommodate up to four people at times. ${ }^{6}$

Expensive building costs are also part of the root cause of the housing affordability problem. The Aotearoa New Zealand building industry is tiny by world standards, with a limited supply of both labour and materials. It is constrained by the comparatively higher costs arising from its small market and low local demand for manufacturing, its dependence on imports, and its distance from large export markets. The industry currently meets the demand for affordable housing by minimising the size and quality of 'affordable' houses, and targeting the parts of the market that can afford a new house, because whether a house is 'affordable' depends somewhat on the type of household seeking to buy it. ${ }^{\text {? }}$

The cooperative housing model can address the affordability problem generated by our current free market, capital-investment approach to housing. Housing in Aotearoa New Zealand is conceived as a vehicle for financial savings and investment as much as it is for providing people with homes, and it has been a great investment for some. The dominant, separate-titled property basis of our housing creates competition for limited land and housing resources, fuelling financial speculation and increasing housing costs. The political failure to introduce a capital-gains tax to address the housing speculation problem demonstrates that the majority of New Zealanders who own property are content with the status quo. Property owners who have, by hard work, inheritance, or lucky timing, gained access to the property market accrue extra capital value from market shifts most years. When this happens, another group of New Zealanders

5 Shamubeel Eaqub and Selena Eaqub, Generation Rent: Rethinking New Zealand's Priorities (Wellington: BWB, 2015), 67-68; Mark Southcombe, 'The City of Privilege,' Architecture Now, 27 September 2016.

6 Philippa Howden-Chapman, Home Truths: Confronting New Zealand's Housing Crisis (Wellington: BWB, 2015), 11.

7 Howden-Chapman, Home Truths, 24. 
without access to property ownership sees their hopes of owning their own home slip ever further away. Home ownership in Aotearoa New Zealand has become an impossible dream for many. Property values and rental costs have both risen at four times the rate that incomes have grown. ${ }^{8}$ The housing-as-investment system effectively trades off secure housing access for all in return for individualised capital gains and ever-increasing wealth for some. The right to access housing ownership is also a right to live in a secure home and have agency over it. The availability of housing and the quality of housing has health and wellbeing implications for those who cannot afford it.' There is clearly an urgent need to address the hollowing out of the welfare state and the loss of the common expectations of 'prosperity for all' that animated a collectivist ethos in Aotearoa New Zealand from the period of the first Labour government of 1935 through to the election of the neoliberal fourth Labour government of 1984. Access to secure, affordable, reasonable quality housing is as fundamental to the wellbeing of our society as education or health services. There is a need to re-socialise Aotearoa New Zealand housing to address decreasing access to housing.

\section{Papakāinga and marae-based housing}

At a recent presentation I gave on cooperative housing, a participant noted that papakāinga, the traditional form of Māori housing, are the original Aotearoa model of cooperative housing. ${ }^{10}$ As Bill McKay has shown, Māori have long lived in collective settings on their land. ${ }^{11}$ In 2019, only five

8 Susan Edmunds, 'Renters' incomes struggle to keep up with rising cost of housing,' The Dominion, 22 November 2019.

9 Howden-Chapman, Home Truths, 68-73.

10 Mark Southcombe, 'Iwi Leaders Forum,' Callaghan Innovation, Gracefield, Lower Hutt, 19 February 2020.

11 Bill McKay, 'Māori Settlement and Papakāinga', CoHoHui, VUW Faculty of Architecture and Design, 12 February 2019. 
percent of Aotearoa New Zealand land was Māori land. ${ }^{12}$ In papakāinga and marae-based housing, we have an exemplary Indigenous community model that integrates land held in common with shared facilities, housing, and highly functioning social structures. ${ }^{13}$ This historic settlement pattern was disrupted by colonisation and its many effects, including legislation such as the Town and Country Planning Act that made it illegal for Māori communities to live collectively if the land they were living on was zoned as rural. ${ }^{14}$ The act allowed only one dwelling on large, rural, collectively owned plots. There were negative effects on Māori communities and identity arising from changed housing patterns after the demolition of historic papakāinga and their replacement with individualised state houses. ${ }^{15}$

Independent of planning impediments, there remain significant difficulties to building housing on collectively owned Māori land. Governance with multiple ownership interests makes decision-making problematic. ${ }^{16}$ Banks have historically been reluctant to lend for Māori housing because collectively owned land cannot be sold to provide security for the loans. When banks have funded projects it has been in a significantly reduced manner, most often without the site-based infrastructure component (for services such as sewerage and power connection) and requiring the housing units to be relocatable, so that they can be moved off site if the loan is defaulted.

Work has occurred in recent years to address these issues and some progress has been made. Alternative governance processes have been possible

12 Jessica Smith, 'Papakāinga the power of partnerships,' CoHoHui, VUW Faculty of Architecture and Design, 12 February 2019.

13 M. R. Austin, 'A Description of the Māori Marae,' Study Paper no. 30, University of Auckland School of Architecture.

14 Paul Dalziel, Hirini Matunga, and Caroline Saunders, 'Cultural Well-Being and Local Government: Lessons from New Zealand,' Australasian Journal of Regional Studies 12, no. 3 (2006): 267-280.

15 I. H. Kawharu, 'Orakei: A Ngati Whatua Community,' Wellington, New Zealand Council for Educational Research, 1952, 268.

16 The New Zealand Te Ture Whenua Māori Act 1993 requires 70 percent of owners to agree on any land partitioning. 
since 1993, and guarantees and security mechanisms are also possible to underwrite lending risks. The difficulty of financing and developing Māori land that is held in common has sometimes protected it from subdivision and dispersal over an extended period. ${ }^{17}$ Where land remains in common ownership, it remains potentially available for occupation and use by current or future generations in a way that could not happen following subdivision and the introduction of private ownership. This is a critical advantage of commonly held land.

There is a contemporary renaissance of papakāinga housing projects and valuable research under way; many projects are in the planning phases and some high-profile exemplars have been completed. There are also projects underway to develop contemporary papakāinga. ${ }^{18}$ There is much to learn from the experience of different iwi and whānau who are in the process of establishing housing on commonly owned land. Despite some successes in this area, projects to establish new papakāinga continue to face similar legal, financial, and social issues to those faced by other collective and cooperative housing models emerging in Aotearoa New Zealand. Contemporary papakāinga projects, and their long history, signals that cooperative housing models are not novel to these shores, and that they are not only desirable, they are possible.

17 At the CoHoHui, Jessica Smith noted that ' 80 percent Māori land is underutilized and underperforming'.

18 See: Jade Kake, Rebuilding the Käinga: Lessons from Te Ao Huriburi (Wellington: BWB, 2019); Derek Kawiti, 'Urban Papakāinga: Programming Cultural Criteria by Using Multi-Agent Systems,' Fifty Years Later: Revisiting the Role of Architectural Science in Design and Practice, $50^{\text {th }}$ International Conference of the Architectural Science Association, December 2016; Stevens Lawson and Ngāti Whātua, Kainga Tuatahi, a 30 home Papakāinga housing development in Ōrākei, https:/www. stevenslawson.co.nz/projects/kainga-tuatahi-housing/; Roger Walker and Tenths Trust, Te Aro Pā, a 14 home papakāinga housing development in Wellington, http:// www.communityhousing.org.nz/Downloads/Assets/Download/13653/1/Dwell\%20 housing\%20partnership \%20Te\%20Aro\%20Pa\%20-final.pdf 


\section{Emerging collective housing and land tenure}

In addition to papakāinga, a range of community-based collective housing projects are in development across Aotearoa New Zealand. In February 2019, a group of researchers aiming to connect and facilitate this emerging housing sector co-facilitated a national collective urban housing symposium called CoHoHui. ${ }^{19}$ It brought together most of Aotearoa New Zealand's established and emerging collective housing groups for workshops and the exchange of ideas. Soon after, the international co-housing expert Michael LaFond was invited to the country to give presentations and meet with locals and community leaders across five cities. An international exhibition titled CoHousing Inclusive was shown in Wellington, Christchurch, and Auckland from February to June 2019. LaFond's experience of the pitfalls and potentials of many European communities inspired and helped to flesh-out alternative community-based housing visions of community-led, procured, and managed housing for Aotearoa New Zealand. The success of these events, which were all well attended, indicates there is a growing appetite for alternative housing models in the country.

Alongside this growing openness to collective housing models are a multitude of misconceptions as to what the different types of communitybased and shared housing models are, which are regularly confused with one another. Co-housing, as a model, is distinct from both co-living and cooperative housing, and is very different to communes and philosophically driven intentional communities. Members of the Buckley Road co-housing project in Wellington, for example, experienced both positive curiosity and gross misperceptions about their co-housing project-with their real estate agent going so far as to describe them as a cult. ${ }^{20}$ Every community based project will differ in its composition and aspirations, establishment and governance processes, and the built implications of these. To bring some

19 Thomas Nash, Damian Sligo-Green, Mark Southcombe, and Carine Stewart, CoHoHui, VUW Faculty of Architecture and Design, 12 February 2019.

20 Tania Sawicki Mead and Nicole McCrossin, 'Buckley Road CoHousing,' CoHoHui, VUW Faculty of Architecture and Design, 12 February 2019. 
clarity to the discussion, I will outline some of the more common communitybased models before discussing cooperative housing in more depth.

\section{Collective-housing types}

Co-living is investor-owned, multiple-occupancy residential housing with some shared living components. It includes rental hostels, rental-serviced accommodation units with some shared spaces, and cluster apartments. Individuals and investors own co-living accommodation, with the focus being the provision of efficient, small, short-term residential tenancies that have high investment yields. ${ }^{21}$ Co-living typically results in minimal amounts of individually allocated space used for periodic or short-term occupancy, with access to shared spaces such as lounges, kitchens, dining rooms, and co-working spaces. ${ }^{22}$

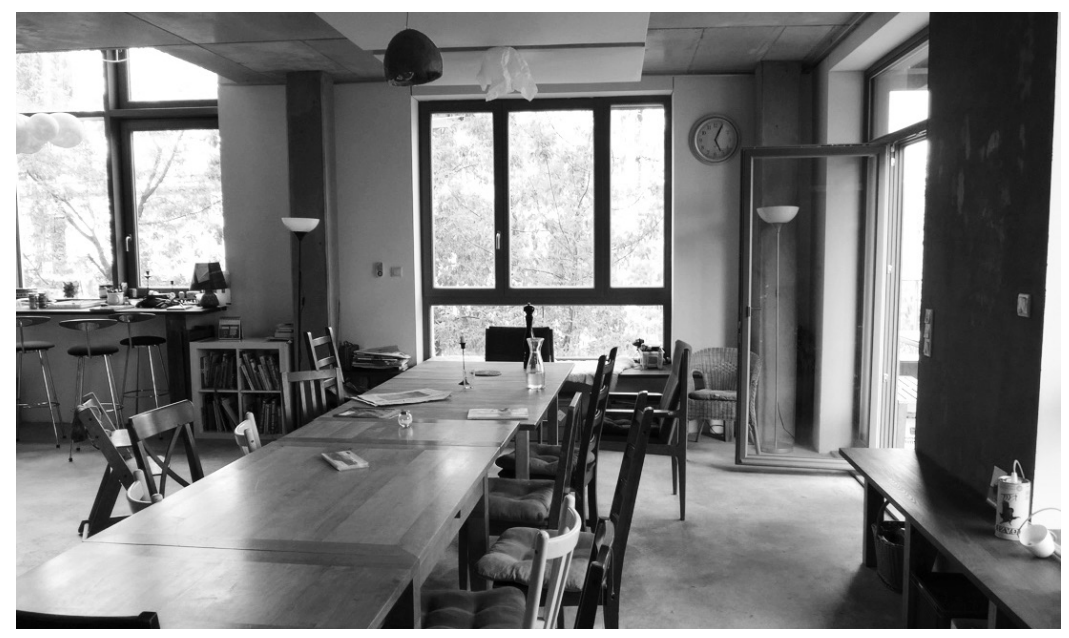

Figure 1. Dining table in cluster apartment, Spreefeld Cooperative, Berlin.

21 Mark Southcombe, 'When co-living housing is just a fancy name for exploiting a crisis,' The Spinoff, 21 June 2019.

22 Coh is a co-living 22-bedroom project at the top of Symonds Street in Auckland. 
Cluster apartments are like shared flats that consist of a number of small, exclusive access zones, such as bedrooms, that may also be grouped with private-use facilities, such as a bathroom, living space, or kitchenette. They also share common social spaces such as kitchen, dining, and lounge facilities. Cluster apartments may be part of co-living, co-housing, or cooperative housing governance structures. ${ }^{23}$

Co-housing is an elective community of self-contained houses or apartments that also share common space and facilities, such as a common lounge, kitchen, dining, laundry, community garden, and storage. There are many different types of co-housing communities. ${ }^{24}$ Key to understanding this diversity is recognising the two main types of co-housing project. The first is the baugruppen (building group) model, which focuses on collective building procurement. As I have written elsewhere:

Baugruppen vary greatly in their management, but most are initiated and led by a small team or a project champion, such as an architect or developer, who invites client group participation at significant points of the design and build process. The extent of a baugruppen's shared space and community emphasis varies-from very little, if any, through to very significant. Baugruppen are just as likely to be motivated by the search for affordable and diverse collective real estate development as they are to be driven by a desire to create community. ${ }^{25}$

Nightingale Housing in Melbourne is an often-referenced exemplar of a successful co-housing model based on the German baugruppen model. Like many Aotearoa New Zealand co-housing projects, it is a community-based, collective development and investment, co-housing ownership model.

23 For example, Michael LaFond's apartment within the co-housing cooperative at Spreefeld in Berlin is a cluster apartment with 24 occupants.

24 Michael LaFond, Cohousing Cultures: Handbook for Self-Organized, CommunityOriented and Sustainable Housing (Berlin: Jovis, 2012).

25 Mark Southcombe, 'Emerging Collective Housing Build,' Build no. 168 (2018): 55-56; Kirsten Ring, Selfmade City: Self-Initiated Urban Living and Architectural Interventions (Berlin: Jovis, 2013). 
Nightingale's key difference is that its processes are professionally facilitated, documented, and repeated in the manner of a franchise. Baugruppen are typically larger in scale and have optimised, efficient community facility provision, which means they can be more cost efficient than equivalent market housing. Significant savings are made on some of the usual development costs through direct collective building procurement at net cost, without developer margins and marketing costs. Cutting out the developer, the profit margin, and any marketing costs typically reduces the price of an apartment in Berlin by around 25 to 30 percent. ${ }^{26}$

The second type of co-housing is the baugermeinshaft (building community) model, which emphasises the social component of housingbuilding a community and living together after construction. For baugermeinshaft, the foundation of the community is laid through investing time into building social connectedness. To this end, they will often engage in specialist group facilitation and utilise participatory, bottom-up processes of decision-making. ${ }^{27}$

Baugermeinshaft groups are similar to the original Danish co-housing models that emerged in the 1970s. This co-housing model takes longer to establish due to the time given to group formation and development, and wider grass-roots communication and management structures than occurs with baugruppen projects. ${ }^{28}$ From what I have observed, the costs of developing a baugermeinshaft co-housing project are higher than those of other co-housing models. This is due mostly to the extra time taken to realise the project and the greater investment in extensive community facilities. ${ }^{29}$

26 Andreas Ruby and Nathalie Janson, 'Listen,' Blueprint no. 332 (2014).

27 Southcombe, 'Emerging Collective Housing Build,' 55-56.

28 Helen Jarvis, 'Towards a Deeper Understanding of the Social Architecture of Cohousing: Evidence From the UK, USA and Australia,' in The Re-Emergence of Co-Housing in Europe, ed. Lidewij Tummers (Abingdon: Routledge, 2017). This is also the New Zealand experience for Delhi Village in Whanganui and High Street Cohousing in Dunedin, which both took seven years to be realised.

29 Tim Ross, 'High Street CoHousing,' CoHoHui, VUW Faculty of Architecture and Design, 12 February 2019, reported on the extent of increased costs and associated delays over the time taken to realise the project. 
The cost of developing such a project, however, is still comparable too, if not a little less than, buying into new-build, individually titled, conventionally constructed housing.

Cooperative housing is similar to baugermeinshaft co-housing in its design and grass-roots community focus, and the two are often confused. The key difference between almost all Aotearoa New Zealand co-housing and European cooperative housing is that co-housing here almost always retains an individual unit-titled property ownership structure. Many of the most well-known European co-housing exemplars regularly referenced in Aotearoa New Zealand have shared governance and ownership formalised through cooperative housing legal structures. ${ }^{30}$ In Aotearoa New Zealand, we have a long-established (although numerically small) community-based co-housing sector, but few, if any, true cooperative housing examples. ${ }^{31} \mathrm{We}$ need to urgently introduce cooperative housing to Aotearoa New Zealand to help address the affordability and associated social sustainability of our current housing models.

\section{What is cooperative housing?}

In Aotearoa New Zealand, cooperatives are user-owned and controlled businesses where benefits are derived and distributed equitably, based on use. Members acquire shares in the cooperative, and in turn receive a lifelong security of tenure, which can be passed onto children. Cooperative societies originally emerged from the working-class cooperative movement in northern England, where the Rochdale Cooperative Principles for cooperative organisation were adopted to guide their operation; in 1861 the Rochdale Pioneer Land and Building Company built the first cooperative

30 Mehr als Wohnen in Zurich, Sargfabric in Vienna, and Spreefeld in Berlin are all co-housing that are structured and governed as cooperative housing.

31 In addition to historic papakainga and the remnants of the Ohu movement, the Quaker settlement, Riverside, and Earthsong are long established in Aotearoa New Zealand. 
housing there. ${ }^{32}$ In Germany, cooperative housing was also created as a response to the housing pressures and economic tensions associated with the Industrial Revolution. ${ }^{33}$ Rapid urban population growth had created a huge housing deficit, which resulted in overcrowding. Housing cooperatives emerged as a self-help response to the housing crisis: workers, craftsmen, and employees set up cooperatives, often supported by local governments, philanthropic organisations, or socially responsible employers. ${ }^{34}$ The cooperative housing model continues through to the present day across Europe and the UK where it is growing.

While there are many cooperative businesses and papakāinga in Aotearoa New Zealand, there is little evidence of formalised cooperative housing. There are some company share apartments, which were built prior to 1972, with some cooperative characteristics, and the Peterborough Housing Cooperative which has shared land and some trust-owned rental apartments. ${ }^{35}$

Cooperative housing varies in its different manifestations around the globe, but there are important commonalities. Cooperatives have shared ownership of land and housing. Members typically pool their resources in a shared-ownership, not-for-profit company. In cooperative housing, the investors are the users. Cooperatives, in a similar manner to co-housing, share a range of common facilities, which might include a common kitchen,

32 Johnston Birchall, 'The Hidden History of Cooperative Housing in Britain,' Brunel University Department of Government Working Paper no. 17, 1991, 4.

33 Jack Shaffer, Historical Dictionary of the Cooperative Movement (Lanham: Scarecrow Press, 1999), 236.

34 Manual Lutz, 'Lived Solidarity: Housing Co-operatives,' Assemble Papers, 20 November 2019.

35 Robin Skinner, 'Pemberton's Happy Colony: Reappraising the Reception and Legacy of a Nineteenth-Century Utopia,' Fabrications 27, no. 3 (2017): 376-395, documents an 1854 unbuilt visionary proposal intended for Taranaki and influenced by the working-class cooperative movement. Prior to the introduction of the Unit Titles Act 1972, there were many company-share apartment arrangements with shared components, including some similar to cooperatives - for example, the approval of new owners by existing residents. Peterborough Housing Cooperative in Christchurch is the closest Aotearoa New Zealand example of a true cooperative uncovered by this research to date. 
a dining and meeting lounge, library or music rooms, laundry, gardens, washing lines, and BBQ areas. The key difference to co-housing is that cooperatives eschew individual-ownership structures and the associated individual emphasis. They often also bulk purchase energy, insurance, and regular ongoing costs such as food.

In Germany, cooperative housing members acquire shares in the cooperative real estate. At the same time, this is associated with a lifelong right to use a cooperative apartment. Members are both tenants and shareholders of the cooperative housing company. ${ }^{36}$ The initial cost of shares to establish a cooperative is paid for by the foundational cooperative residents. Rental prices are set to cover the costs of building, finance, and maintenance, but nothing more. In practice, rents are not only secure, but can decrease over time, like mortgage payments do as debt is retired.

Members can exit by selling their shares, but only to other members or approved new residents if no members want to take up the available share sale option. This also allows members the option to shift house within the same cooperative, creating the opportunity to upsize or downsize at a reasonable cost and within a set process and period. Apartments may be split into two or combined with an adjacent apartment as part of a sale process. ${ }^{37}$ Because they are affordable, shares in existing cooperatives are typically in high demand. ${ }^{38}$ The share sale value, which is set by the cooperative, is the original investment paid back to the original owner, with modest interest-which is much lower than one would expect from an equivalent

36 See: https://www.bundesregierung.de/breg-de/aktuelles/fuer-bezahlbare-mietenunverzichtbar-430250

37 Sargfabrik is designed to accommodate a 'Divorce Model' where apartments can be split in two if two cohabitating cooperative members separate. This has happened sometimes, with both residents remaining in the community. Frank Schilder and Mark Southcombe, unpublished interview, BKK-3 Architects, Sargfabrik, Vienna, May 2016.

38 Joan Ruan Nielson noted that the affordability and associated demand to join existing housing cooperatives is so high in Copenhagen that potential cooperative members sometimes offer extra financial inducements for the chance to purchase available shares. Joan Ruan Nielson and Mark Southcombe, unpublished interview, Spektrum Architects, Danish Housing Cooperative, May 2016. 
market-based housing profit. This system recognises the value the occupant has had from the housing over the time spent living there. Cooperative members receive all the benefits of home ownership at an affordable buyin rate, with affordable ongoing costs, and without the speculative capital gain component of housing. The relative costs of belonging to a cooperative may decrease over time, resulting in increased disposable income becoming available to residents. This acts as an incentive for residents to remain in the housing cooperative for as long as they can. It also results in increasingly diverse human resources within cooperative communities over time as residents' personal circumstances change. Cooperative members with relatively high levels of disposable income coexist with those who have less income, or who may not be working. ${ }^{39}$ Housing cooperatives have an inbuilt emphasis on democracy, equality, and solidarity within a long-term, stable community. ${ }^{40}$ It is also common for cooperatives to be structured to have a permanent (usually 20 percent) social rental component that offers the same standard of accommodation and collective benefits enjoyed by shareholders, sometimes with a margin included to cover the extra financial and administration costs of the rental tenure component of the housing.

Governance of cooperative housing is also different to that of a unittitled structure, where management of the body corporate is undertaken by the elected few on behalf of the majority. Cooperatives' different philosophical basis is reflected in their inclusive, self-managing 'Housing Association' structures, which share responsibilities between many residents and small groups. The legal form of the registered cooperative in Germany is based on principles of self-organisation, self-help, and personal responsibility. These principles are legally guaranteed by their Federal Government Cooperative Act. ${ }^{41}$ Cooperative, grassroots social management structures also recognise the value of efforts undertaken for the good of the

39 Frank Schilder noted that a well-known Austrian politician remained living in the housing cooperative he was a part of over the length of his career. Schilder and Southcombe, unpublished interview.

40 Lutz, 'Lived Solidarity.'

41 German Federal Government, 'Cooperative Housing Act 1889' (amended in 2006 to facilitate smaller cooperatives). 
collective, saving ongoing management and maintenance costs through the value of community-labour inputs. Like co-housing communities, with membership comes responsibility. Members are expected to attend governance meetings (especially during the set-up period) and to contribute labour to community projects like a community garden, or cleaning up after a community event. ${ }^{42}$ Engagement in this social side of a community typically occurs on a 20 percent very engaged, 60 percent somewhat engaged, and 20 percent disengaged basis, and this changes over time as residents' life circumstances and availability change. ${ }^{43}$

Housing cooperatives are socially sustainable. They facilitate social connections that provide informal, readily available social support. Most cooperative housing residents have a surplus of social capital, which they invest in their community. In return, they get a nice neighbourhood and a lot of friends. ${ }^{44}$ Most cooperatives are structured to create long-term, diverse, inclusive communities through fostering a variation of resident's ages, residential groupings, and backgrounds. ${ }^{45}$ The shared components of the housing facilitate the formation of social connections and associated positive health outcomes from reduced isolation, loneliness, and anxiety. ${ }^{46}$ Die Wohnungsbaugenossenschaften Deutschland (the marketing initiative of the cooperative housing associations in Germany) explains this as follows:

Cooperatives offer a wide range of options for realising cooperative living in solidarity with the other members. Whether this is the support

42 This is similar to the 'co-housing tax' (sweat-equity contribution) discussed by Katheryn McCamant and Charles Durrett, Creating Cohousing: Building Sustainable Communities (Gabriola Island: New Society Publishers, 2011), 19.

43 Schilder and Southcombe, unpublished interview.

44 LaFond, Cohousing Cultures.

45 Urban Habitat Collective in Wellington have similar aims for their co-housing project in Adelaide Road, with a third of the project allocated for older people, a third for people with families, and a third for others.

46 Michael LaFond and Larisa Tsvetkova, CoHousing Inclusive: Self-Organised, Community-Led Housing for All (Berlin: Jovis, 2017). See also, Olivia Whyte, It Takes a Village: A Collective Approach to New Zealand Housing (Masters thesis, Victoria University of Wellington, 2019). 
of an elderly neighbour, help for the young family or simply the jointly organised farm festival—each contribution contributes to a pleasant living environment. This lived neighbourhood is an expression of our solidarity. It has always strengthened the cooperatives and is still the guarantor for permanent, safe living. Cooperative members know that they can rely on it. ${ }^{47}$

Social, state, or city rental housing is a preferred part of the housing mix too, with partnership projects sought by various European municipalities who use a variety of tactics to facilitate establishment of new cooperative housing with an associated affordable long-term rental component. ${ }^{48}$

Cooperative housing projects are typically big enough in scale for there to be real savings in the initial build costs through economies of scale and direct collective procurement during the design and construction stages. This helps ensure that the housing costs and relative design diversity and quality are favourably compared to market-designed housing. The diversity of residents' needs is reflected in a variety of housing types and sizes within a cooperative, and long-term design of the homes anticipates the potential for change over time, and for design flexibility within them when required. Cluster apartments with multiple residents can readily co-exist with traditional housing typologies of varying sizes, dependant on the needs of the occupant group. This inevitably results in some social diversity and complementarity in the mix of residents. Finding a design balance between private individual space and accessible common spaces is important for ensuring that residents and visitors are not forced into social interaction when they do not want it, and that they have potential opportunities for social engagement during daily routines. Cooperative communities are very stable because it is in the residents' long-term financial and social interests to stay. As Manual Lutz notes, cooperative members are shareholders of the housing company that they produce and manage together. Each member

47 'This is how a cooperative works', Die Wohnungsbaugenossenscaften Deutschland, https://www.wohnungsbaugenossenschaften.de/genossenschaften/warum-genossenschaft/wie-funktioniert-genossenschaft

48 LaFond and Tsvetkova, CoHousing Inclusive, 18-19. 
has one vote only, irrespective of the number of shares acquired. ${ }^{49}$ The tenure of cooperatives is limited to owner-occupiers, except for an up to 20 percent rental component, or for extraordinary short-term circumstances by agreement of the cooperative.

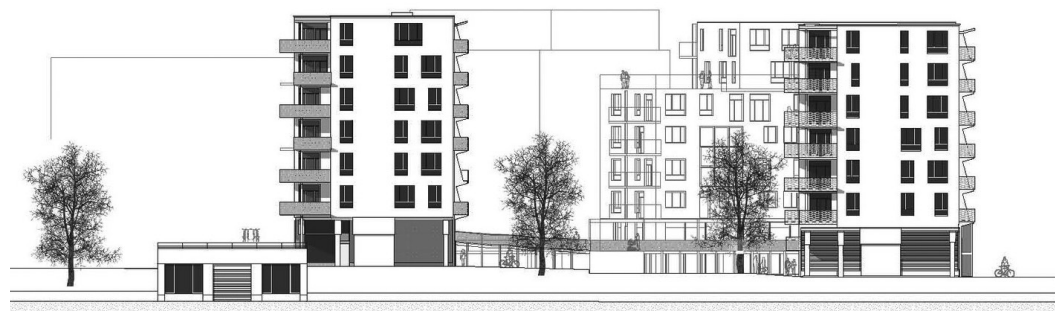

Figure 2. River elevation of three seven-floor apartment buildings at Spreefeld Cooperative, Berlin. Carpaneto Architekten + Fatkoehl + BARarchitecten.

\section{Individual-ownership co-housing or shared-ownership cooperative housing?}

The range of collective housing communities including papakāinga emerging in Aotearoa New Zealand gives hope for a more diverse and socially sustainable future of community-based housing. We need more of these housing types to diversify existing housing options, and this is slowly happening. ${ }^{50}$ Alternative shared housing forms are also attracting public and media interest. Governmental agencies and private developers are beginning to understand how collective housing models are relevant

49 Lutz, 'Lived Solidarity.'

50 Current co-housing projects in Aotearoa New Zealand include: Ahi Wai Village in Whangarei, Cohaus in Auckland, Closer in Tauranga, Cambridge Cohousing, New Plymouth Cohousing, Buckley Road Cohousing in Wellington, Urban Habitat Collective in Wellington, Collet's Corner in Lyttleton, Queenstown Urban Village, and High Street Cohousing in Dunedin. 
in the Aotearoa New Zealand context, how they might operate, and to recognise their potential. These housing models are addressing the needs of some residents who would otherwise not be able to purchase property, or who want to live in a more community-based manner. It is clear, however, that contemporary co-housing projects are not yet addressing long-term housing affordability for anyone but the middle classes.

Co-housing projects and communities are different in their composition and aspirations, establishment processes, and the built implications of these. ${ }^{51}$ What they have in common is the formation of a housing group through shared effort, and the creation of community-focussed housing with some shared components. In contemporary Aotearoa New Zealand, there is little, if any, external financial support for these types of housing, and in my observation, all of the emerging projects struggle to be realised. Those that succeed do so with the help of visionary and determined stakeholders, collective financing, benign investors, or community-based developers..$^{52}$ Some cost efficiencies may accrue to a project through design, sharing of facilities, and collective procurement savings in development margins and marketing costs, or from economies of scale if the project is large enough. There are also the extra costs for community facilities that are not provided in standard housing. It is hard enough for most people to afford to own basic individual houses without needing to fund extra common space as well, so this type of housing is not yet addressing housing affordability in a significant way.

Co-housing communities are motivated to form by the common interests or circumstances of occupants. Lutz suggests that this makes them vulnerable to the loss of this common interest over time. ${ }^{53}$ Co-housing in New Zealand almost always adopts freehold unit-titled ownership, with some common property (shared space) managed through a body

51 Dominic Glamuzina and Aaron Patterson, 'Where is our collective imagination?' Architecture Now, 2 April 2016.

52 Abigail Hurst, 'Co-what? Alternative housing models,' Architecture Now, 9 July 2019.

53 Lutz, 'Lived Solidarity.' 
corporate structure. ${ }^{54}$ This facilitates resale of the freehold title when the owners need or decide to. Individual property ownership and the associated individualised increases in the capital value of the housing create affordability access issues over time for potential new co-housing owners. For example, while ground-breaking sustainable co-housing projects like Earthsong began as affordable in 1999, access by new owners to the unit-titled community in Ranui, Auckland is now valued at a financial level that is far from affordable for first home owners. ${ }^{55}$ Unit-titled cohousing structures inadvertently concentrate wealth for the first generation of owners, and so it becomes progressively more expensive for new generations of first-home-owners to join. Despite good intentions, most individually owned co-housing inadvertently remains part of the propertyas-investment housing affordability problem. ${ }^{56}$

Individual ownership and shared ownership are the key difference between co-housing and cooperative housing. Cooperatives emerged through people with housing needs responding to local housing shortages and affordability issues. This approach to housing is incompatible with a view of housing that sees it primarily as an investment exposed to the vagaries of the market. Cooperatives provide an enduring, and often expanding, legacy of affordable housing in stark contrast to individually owned housing models. As Lutz notes, 'Housing co-operatives are by now a well-established form of tenure in the German-speaking countries, acknowledged for producing durably affordable rents (on average, below

54 There are exceptions such as the Quaker Settlement in Whanganui, which has its land held by a trust and residents purchase a license to occupy the land. The houses are owned by the residents but must be sold back through the trust so that the social cohesion of the group can be maintained. Peterborough Housing Cooperative in Christchurch also has its land held in common by a trust with its houses individually owned.

55 Robyn Allison and Mark Southcombe, private communication about Earthsong, Wellington, February 2019.

56 For example, a villa for sale 'at-cost, non-profit' basis in the Cohaus co-housing project in Surrey Crescent, Auckland has an asking price of \$1,720,000. See: http:// cohaus.nz/ 
market rent) and stable neighbourhoods'. ${ }^{57}$ Alongside owner-occupied residential and rental properties, cooperatives offer a third potential 'pillar' of housing supply in Aotearoa New Zealand, as occurs in Germany.

\section{Between ownership and rental-investment housing}

Cooperative housing is a genuine alternative to our entrenched housing patterns, offering long-term security of tenure advantages similar to housing ownership, and relative affordability superior to long-term rental accommodation.

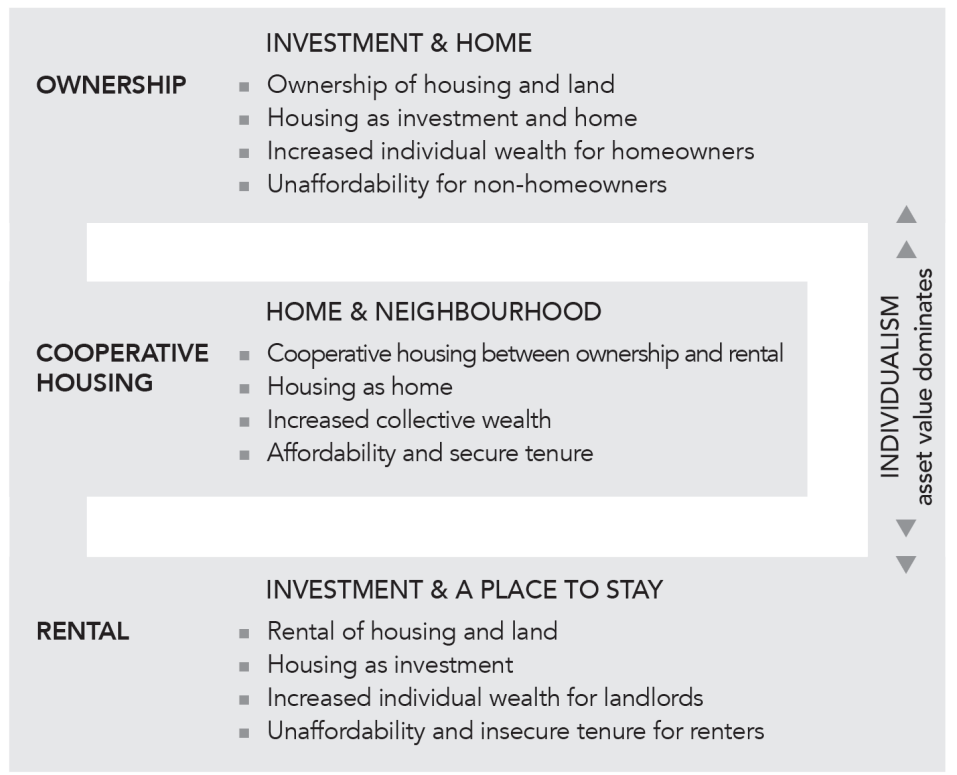

Figure 3. Third pillar housing.

The lack of built cooperative housing precedents and history in Aotearoa New Zealand mean the practicality and relevance of cooperative housing models is frequently misunderstood and underappreciated. As a researcher active 
in this field, it is clear to me that a lack of knowledge and understanding of cooperative housing inhibits serious consideration and uptake. Many people I discuss this research with are focussed on individual housing solutions and are sceptical about the practicality of sharing of resources or living spaces, as they believe this would impinge upon their autonomy. ${ }^{58}$

When Genevieve Walsh researched Sargfabrik cooperative co-housing in Vienna, she noticed a palpable difference in the social aspects of their housing and wondered, 'Why couldn't this happen in New Zealand?' This motivated her to translate the European cooperative model to the Aotearoa New Zealand cultural context. ${ }^{59}$ Walsh's experiences in Vienna, and my own research in European cities such as Copenhagen, Berlin, Vienna, and London, suggests that other cultures have different perceptions of housing's social role. The residents of these cities can visit working examples of working cooperative housing. Māori with experience of collective living also readily understand the potentials of cooperative housing to create long-term shared-housing solutions. ${ }^{60}$ Aotearoa New Zealand also has many longstanding and successful cooperatives that operate as not-forprofit incorporated societies, including Farmlands, Foodstuffs, ITM, Mitre 10 Builders Merchants, Southern Cross Healthcare, the Cooperative Bank, and FMG Insurance. There are, however, no examples of cooperative housing in the European tradition of shared land and housing that I have discovered, except for Peterborough Housing Cooperative in Christchurch. Peterborough is a co-housing exemplar that also includes vital cooperative housing ingredients, with land and some rental units owned in common by

58 Martin Field, Thinking About CoHousing: The Creation of Intentional Neighbourhoods (Buckingham: Diggers and Dreamers Publications, 2004), 13-22, gives a good overview of the diversity of the collective housing field and the misperceptions associated with it.

59 Genevieve Walsh, I Want to Share: Balancing Collective and Individual Needs in New Zealand Urban Housing Architecture (MArch(Prof) thesis, Victoria University of Wellington, 2018).

60 Jade Kake, 'Contemporary Papakāinga Design - Principles and Applications,' in Our Voices: Indigeneity and Architecture, eds. Rebecca Kiddle et al (San Francisco: ORO Editions, 2018), 165-166; see also, Kake, 'Spatial Justice-Decolonising Our Cities and Settlements,' this issue. 
a Land Trust; it also has a mixed ownership and rental model through unittitle ownership of the houses. ${ }^{61} \mathrm{New}$ housing cooperatives are currently in the planning stage for Closer in Tauranga, Ohu in Christchurch, and by Tūhoe in Tāneatua-if successful, they may in time be examples of a true Aotearoa New Zealand housing cooperative. ${ }^{62}$

\section{Cooperative housing as a 'cultural treasure'}

Emma Jones and Philip Shelley argue that the availability of affordable housing in cooperative developments is no accident. ${ }^{63}$ In 2016, UNESCO World Heritage formally recognised the idea and practice of organising shared interests in cooperatives as a cultural treasure. ${ }^{64}$ Cooperatives are recognised for their contribution to long-term housing affordability, and for their stabilising effect for the social fabric due to their creation of stable, enduring communities and increasing the prosperity of their members. In many places with established housing cooperatives, they are also able to provide equity to support the establishment of new housing cooperatives, sustaining and expanding the stocks of long-term affordable housing. ${ }^{65}$ The recent Swiss 1,000-person cooperative project Mehr als Wohnen ('More than Living') in Zurich is a cluster of new cooperatives supported by institutional partners and several older cooperatives who act

61 See: http://www.peterborough.nz/

62 Closer Developments aim to create a housing cooperative in Katikati; Ohu Madras Street development was considering a cooperative structure; and Tūhoe plan to build a 25-unit cooperative eco village at the old Tāneatua railway yard.

63 Emma Letizia Jones and Philip Shelley, 'How housing co-operatives built a city', Architectural Review, 4 October 2016.

64 See: https://ich.unesco.org/en/RL/idea-and-practice-of-organizing-sharedinterests-in-cooperatives-01200

65 Mehr als Wohnen is one of the largest and most ambitious cooperative housing programmes in Europe, resulting from a collaboration between 50 different cooperatives: 13 buildings with nearly 400 housing units, 35 retail units, and large shared community spaces and neighbourhood infrastructure (kindergarten, day care centres, and so on). See: https://www.world-habitat.org/world-habitat-awards/ winners-and-finalists/more-than-housing/ 
as not-for-profit developers. ${ }^{66}$ It also won the World Habitat Awards in 2016. ${ }^{67}$ Imagine an Aotearoa New Zealand cooperative housing model tailored to our legal, financial, cultural, and social context that over time creates a similarly expanding and affordable housing legacy as the housing cooperatives in Europe. It is an exciting and achievable vision with a proven and recognised international history we can learn from.

\section{What needs to change?}

There are barriers to cooperative housing establishment in Aotearoa New Zealand, as also experienced by those working to establish papakāinga and co-housing projects here. Some perceptual and practical changes that would facilitate the emergence of an Aotearoa New Zealand cooperative housing sector are summarised below.

\section{A house is more than an investment}

Aotearoa New Zealand housing perceptions need to be reoriented to become primarily focussed on providing quality, affordable homes and neighbourhoods for people. The dominant approach to housing in Aotearoa New Zealand conflates financial investment with the provision of housing, confusing financial security with housing security. Housing as an asset is not the same thing as housing as a secure place to live, as was evident during the 2007-2009 financial crisis. During that period, housing in many places around the world lost significant, and sometimes all, of its financial value. The majority of those houses remained capable of being homes for their occupants, but the loss of financial value resulted in many evictions. ${ }^{68}$

66 Anna Haller et al, 'Mehr Als Wohnen: A Vision Becomes Reality - 10 Years Lessons Learned,' Zurich, 2017.

67 See: https:/www.world-habitat.org/world-habitat-awards/winners-and-finalists/ more-than-housing/

68 Padraic Kenna et al, Loss of Homes and Evictions Across Europe: A Comparative Legal and Policy Examination (Cheltenham: Edgar Elgar Publishing, 2018), 3-9. 


\section{Long-term housing-tenure stability}

Housing provision and policy need to address long-term affordability, stability, and security of tenure. The high cost, poor quality, and lack of long-term security in Aotearoa New Zealand rental housing results in tenants frequently moving house. ${ }^{69}$ Most people do not want to regularly move from their home or to re-establish themselves in other locations when given the choice. Security of tenure is important for putting down roots and for making connections to a wider community. The difference that this makes to a society is evident in places that have a continuous history of Indigenous living like Tūhoe Marae Tauarau in Rūātoki, or places that have long-term cooperative housing such as Sargfabrik in Vienna, Spreefeld in Berlin, or in the Nørrebro district of Copenhagen. The depth of people's connection to place and community, the social connectedness and stability of the communities, and the external demand to be a part of them is very strong in these places. Connection is also manifest in the many small initiatives present in these cooperatives, such as early childhood centres, community gardens, cafés, and markets. These initiatives provide services to the cooperative and the surrounding community, and opportunities for work and social exchange within the cooperative membership.

\section{A cooperative-housing vision}

A far-sighted Aotearoa New Zealand cooperative housing vision is needed as a basis for a coordinated, equitable, and safe approach to administrative and financial regulation in this sector. Coordinated research is needed to flesh out a practical, culturally specific, $21^{\text {st }}$-century cooperative housing vision. To be effective, this vision should be paired with the creation of cooperative housing resources to facilitate the establishment of new projects. Every project is in some way different, as evidenced in the wide range of cooperative and co-housing projects being undertaken globally, yet these diverse projects go through similar processes and face common

69 Karen Witten et al, 'Report ER22: The New Zealand Rental Sector,' Wellington, BRANZ, 2017, 100. 
challenges as they form. ${ }^{70}$ The availability of easy-to-adapt resources is important for encouraging the establishment of a cooperative housing building sector, and for facilitating and regularising the financial, legal, and social components of cooperative housing projects. ${ }^{71}$ These same resources would also influence social policy and investment, and guide private sector, central, and local government cooperative housing development.

\section{Political and financial support}

Cooperatives are a self-help response to the housing crisis, but to be most effective in reaching those in need they require support during the establishment phase if they are to be affordable, especially until such a time as some of the pilot projects are realised. Several new communitybased agencies and services have emerged focussed on fostering collective housing development and making a living from facilitating them. ${ }^{72}$ These commercial organisations are collegial, generous, and mutually supportive, but sometimes also have minor conflicts of interest. There is an opportunity to create readily available open-source resources and regulations to protect the establishment of a cooperative housing sector in Aotearoa New Zealand. Legislation should facilitate the formation and operation of housing cooperatives with clear and simple legal structures. This is required to protect the interests of their residents on a continuing basis, as occurs in many European countries such as Austria, Finland, France, Germany, Spain, and the UK. ${ }^{73}$

Support for cooperative housing establishment may also take the form of shared equity through social housing provision agreements, land-tenure grants, or leases, equity financing support and guarantees, or below-market establishment loans through 'ethical banks' or federal

70 La Fond Honeck, Cohousing Cultures, 27-33, discuss the diversity of co-housing communities.

71 See: http://www.collectivecustombuild.org/

72 For examples, see: https:/www.theurbanadvisory.com/what-we-do/; https:// www.closer.org.nz/what-we-do; https://ohu.nz/

73 Cooperatives Europe, 'The Power of Cooperation - Cooperatives Europe Key Statistics 2015,' Cooperatives Europe, 2016. 
or city administrations. Support may also occur through preferential site access and deferred settlements, and long-term, low-return leasehold agreements. Active partnership support also occurs through national and local governments. ${ }^{74}$ Community Land Trusts, philanthropic organisations, and socially responsible employers also support cooperative housing to establish on the basis of the proven history of delivering long-term, stable and affordable housing. ${ }^{75}$

\section{Direct collective-housing procurement}

The speculative component of housing in Aotearoa New Zealand dominates housing production and works against potential long-term housing affordability. Housing is predominantly procured within a developerfocussed market that financially incentivises projects to reduce the quality of builds while simultaneously seeking to increase the cost for buyers. ${ }^{76}$ Direct collective building procurement needs to be recognised as a key means of providing better quality, more diverse design, and better value for major housing procurement.

\section{Perception shift}

The misperception of the impracticality of cooperative housing needs to be changed. The qualities and effects of cooperative housing need to be positively demonstrated to address a similar degree of misperception as that once faced around prefabrication in Aotearoa New Zealand. ${ }^{77}$ This will require ongoing education programmes, including public lectures, exhibitions, exchanges, and a national collective housing association with

74 Sigrid Schaefer et al, 'Housing Cooperatives as Partners of the Municipalities,' Best Practice Report, BBSR Special Publication, 2016.

75 German Federal Government, 'Indispensable for affordable rents,' German Federal Government, 19 July 2017.

76 Southcombe, 'The City of Privilege,' 36.

77 Pamela Bell and Mark Southcombe, Kiwi Prefab: From Cottage to Cutting Edge (Rotorua: Balasoglou Books, 2012), 41-42. 
a wide and diverse membership and a mandate to facilitate cooperative housing projects.

A major tool for shifting perceptions is the construction of prototype projects that can host open days and provide a working demonstration of the benefits of cooperative housing, as occurs in Berlin. ${ }^{78} \mathrm{~A}$ designed and built series of visionary, prototype projects with resolved governance, social, and financial components will give evidence of their value. These projects should be pursued with confidence and should be ambitious in scale, in the manner of state housing in the early Modernist period. ${ }^{79}$ Prototypes should focus on mixed-tenure, social and assisted lower-middle-income housing realms like Mehr als Wohnen. The City of Zurich administration saves millions of dollars a year by enabling cooperatives to operate. ${ }^{80}$

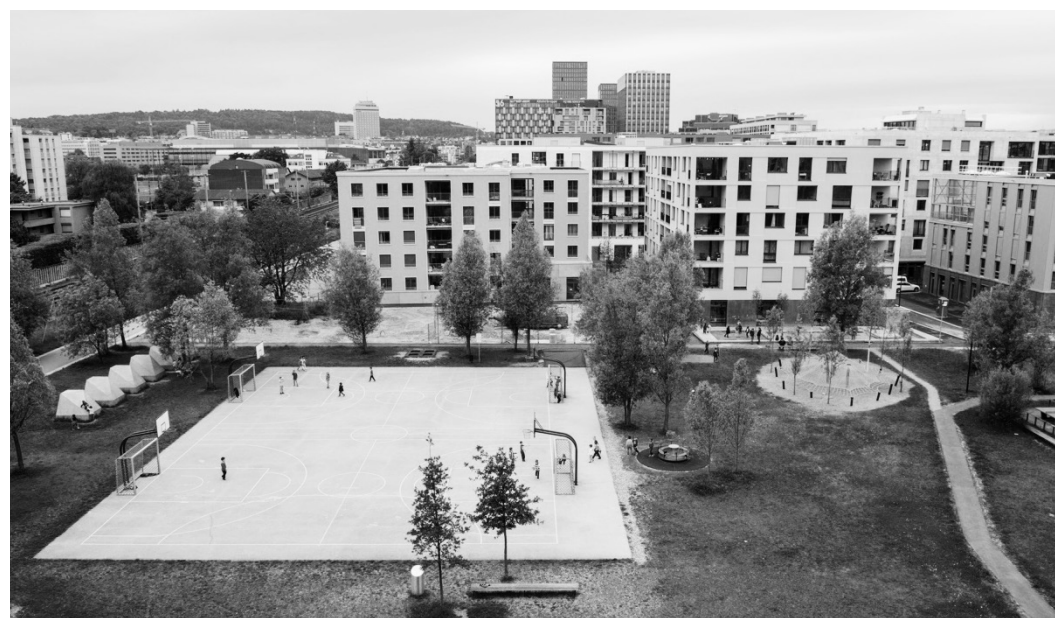

Figure 4. Mehr als Wohnen cooperative housing and landscape, Zurich. Roseli Ferreira, 2020.

78 ID22, the Berlin Institute for Creative Sustainability, runs regular 'experiment days' where wider communities can visit and engage with cooperative and co-housing communities. See: https://experimentdays.de/2018/

79 Julia Gately and Paul Walker, Vertical Living: The Architectural Centre and the Remaking of Wellington (Auckland: Auckland University Press, 2014), 10.

80 Jones and Shelley, 'How housing co-operatives built a city.' 


\section{A $21^{\text {st }}$-century Aotearoa New Zealand cooperative- housing-sector vision}

You only succeed when you stop failing. ${ }^{81}$ A bold new vision is required if everyone in Aotearoa New Zealand is to have access to inclusive and affordable housing. If given the necessary social and financial infrastructure and support, housing cooperatives have serious, practical potential for providing a third way for achieving secure and affordable housing between home ownership and rental properties. Comparison with international cooperative housing sectors suggests that 10 percent of Aotearoa New Zealand's affordable housing, and up to five percent of all our housing could be cooperative. Cooperative housing utilises the strength of collectives to access, prioritise, and protect the right to occupy and maintain an affordable home indefinitely. In cooperative housing, increases in capital value are a controlled part of a more diverse, inclusive, and accessible housing type. This is due to cooperative's social and financial structures and design, creating a legacy of affordable housing to negate the escalation of property prices. Long-term financial advantages for individuals, neighbourhoods, and societies come from the procurement of collective services within cooperatives, the length of time living in one, and the deep relationships with place and community that result. Cooperatives may also be legally structured to reinvest their surplus ongoing income, which becomes available after their first financial cycle, as equity to seed additional housing cooperatives.

Imagine a future where workers or neighbourhood residents elect to set up cooperative housing together to stabilise their future housing and financial prospects. They use clear, simple resource kits and process pathways as a means to advance their vision. Central and local governments, and philanthropic organisations, offer low interest, and deferred-payment loans to facilitate cooperatives in their district. Individuals and organisations want to be foundation cooperative supporters, secure in the knowledge that they are creating an enduring community and a legacy of quality affordable 
housing, free of speculation. They would value helping create a stable, affordable housing base for employees, colleagues, neighbours, and friends. Imagine legislative support for marae-based cooperative housing projects with similar forms of common stewardship to those already occurring with Māori land, and with ongoing resident occupation rights transferable to whānau. A major cooperative housing project in Queenstown or Auckland could create an enduring supply of affordable accommodation for middleand lower-income workers.

The vision for an Aotearoa New Zealand cooperative housing sector offered here seeks to augment ownership and rental housing models, not replace them. It is not an out-of-reach dream, it is an internationally recognised, culturally treasured reality that has proven its value for well over 150 years. This alternative to the market is a bottom-up, self-help model for people with housing needs who, together, set up housing cooperatives facilitated through supportive partnerships. Targeted ongoing research, education, funding, and political initiatives are needed to support these emerging cooperative communities. Visionary Aotearoa New Zealandspecific cooperative housing legislation, if achieved, would support and protect member's rights and responsibilities, their not-for-profit status, and the security of cooperative housing investment, creating an environment conducive to the formation of exemplar projects. Once realised, these highly visible exemplar projects would provide working models, places members of the public could visit and experience first-hand the tangible benefits of cooperative housing — shifting public perception on this model and highlighting its relevance.

This vision for Aotearoa New Zealand housing cooperatives is both present- and future-focussed, and calls for cooperatives to pay it forward and reinvest in new housing cooperatives as their first-generation loans are retired, creating an expanding legacy of affordable housing. Over a 25-year period, the vision of a viable, community-driven, third-way housing sector would be achieved, and become a preferable option to owning or renting a home. Imagine if our cooperative housing projects could receive UNESCO world heritage status as an Aotearoa New Zealand cultural treasure ... our very own housing taonga. This is a dream worth waking up for. 